\title{
Allocation pattern and accumulation potential of carbon stock in natural spruce forests in northwest China
}

\author{
Jun-Wei Yue ${ }^{1,2,3}$, Jin-Hong Guan ${ }^{2}$, Lei Deng ${ }^{4}$ ， Jian-Guo Zhang ${ }^{5}$ ，Guoqing Li ${ }^{1,2}$ ， Sheng Du Corresp. 1, \\ ${ }^{1}$ State Key Laboratory of Soil Erosion and Dryland Farming on Loess Plateau, Institute of Soil and Water Conservation, Chinese Academy of Sciences and \\ Ministry of Water Resources, Yangling, Shaanxi, People's Republic of China \\ 2 Institute of Soil and Water Conservation, Northwest A\&F University, Yangling, Shaanxi, People's Republic of China \\ 3 University of Chinese Academy of Sciences, Beijing, People's Republic of China \\ 4 Academy of Agriculture and Forestry Sciences, Qinghai University, Xining, Qinghai, People's Republic of China \\ 5 Upper and Middle Yellow River Bureau, Yellow River Conservancy Commission of the Ministry of Water Resources, Xi'an, Shaanxi, People's Republic of \\ China \\ Corresponding Author: Sheng Du \\ Email address: shengdu@ms.iswc.ac.cn
}

Background The spruce forests are dominant communities in northwest China, and play a key role in national carbon budgets. However, the patterns of carbon stock distribution and accumulation potential across stand ages are poorly documented.

Methods We investigated the carbon stocks in biomass and soil in the natural spruce forests in the region by surveys on 39 plots. Biomass of tree components were estimated using allometric equations previously established based on tree height and diameter at breast height, while biomass in understory (shrub and herb) and forest floor were determined by total harvesting method. Fine root biomass was estimated by soil coring technique. Carbon stocks in various biomass components and soil $(0-100 \mathrm{~cm})$ were estimated by analyzing the carbon content of each component.

Results The results showed that carbon stock in these forest ecosystems can be as high as $510.1 \mathrm{t} \mathrm{ha}^{-1}$, with an average of $449.4 \mathrm{t} \mathrm{ha}^{-1}$. Carbon stock ranged from 28.1 to $93.9 \mathrm{t} \mathrm{ha}^{-1}$ and from 0.6 to $8.7 \mathrm{t} \mathrm{ha}^{-1}$ with stand ages in trees and deadwoods, respectively. The proportion of shrubs, herbs, fine roots, litter, and deadwoods ranged from $0.1 \%-1 \%$ of the total ecosystem carbon, and was age-independent. Fine roots and deadwood which contribute to about $2 \%$ of the biomass carbon should be attached considerable weight in the investigation of natural forests. Soil carbon stock did not show a changing trend with stand age, ranging from 254.2 to $420.0 \mathrm{t} \mathrm{ha}^{-1}$ with an average of $358.7 \mathrm{t} \mathrm{ha}^{-1}$. The average value of carbon sequestration potential for these forests was estimated as $29.4 \mathrm{t} \mathrm{ha}{ }^{-1}$, with the lower aged ones being the dominant contributor. The maximum carbon sequestration rate was $2.47 \mathrm{t} \mathrm{ha}^{-1}$ year ${ }^{1}$ appearing in the growth stage of 37-56 years.

Conclusion The carbon stock in biomass was the major contributor to the increment of carbon stock in ecosystems. Stand age is not a good predictor of soil carbon stocks and accurate evaluation of the soil carbon dynamics thus requires long-term monitoring in situ. The results not only revealed carbon stock status and dynamics in these natural forests but were helpful to understand the role of Natural Forest Protection project in forest carbon sequestration as well. 
1 Allocation pattern and accumulation potential of carbon stock in natural spruce forests in

2 northwest China

3 Jun-Wei Yue ${ }^{1,2,5}$, Jin-Hong Guan ${ }^{2}$, Lei Deng ${ }^{3}$, Jian-Guo Zhang ${ }^{4}$, Guoqing Li ${ }^{1,2}$ and Sheng

$4 \mathbf{D u}^{1,2, *}$

$5 \quad{ }^{1}$ State Key Laboratory of Soil Erosion and Dryland Farming on Loess Plateau, Institute of Soil

6 and Water Conservation, Chinese Academy of Sciences and Ministry of Water Resources,

$7 \quad$ Yangling, Shaanxi 712100, China

$8{ }^{2}$ Institute of Soil and Water Conservation, Northwest A\&F University, Yangling, Shaanxi

9712100, China

$10{ }^{3}$ Academy of Agriculture and Forestry Sciences, Qinghai University, Xining, Qinghai 810016,

11 China

$12{ }^{4}$ Upper and Middle Yellow River Bureau, Yellow River Conservancy Commission of the

13 Ministry of Water Resources, Xi'an, Shaanxi 710021, China

$14{ }^{5}$ University of Chinese Academy of Sciences, Beijing 100049, China

15 * Corresponding author: Sheng Du

16 Email: shengdu@ms.iswc.ac.cn; Tel.: +86-29-8701-2411

17 


\section{Abstract}

Background Spruce forests are major forest communities in northwest China and play an important part in national carbon budgets. However, the patterns of carbon stock distribution and accumulation potential across stand ages are poorly documented.

Methods Based on intensive field surveys and sampling on 39 plots, we investigated carbon stocks in both the vegetation biomass and soil horizon of these forest ecosystems. Biomass of tree components were estimated using allometric equations previously established based on tree height and diameter at breast height, while biomass in understory (shrubs and herbs) and forest floor were determined by total harvesting method. Fine root biomass was estimated by soil coring technique. Carbon stocks in various biomass components and soil horizon $(0-100 \mathrm{~cm})$ were estimated by analyzing the carbon content in each component.

Results The results showed that carbon stock in these forest ecosystems can be as high as $510.1 \mathrm{t}$ $\mathrm{ha}^{-1}$, with an average of $449.4 \mathrm{t} \mathrm{ha}^{-1}$. Carbon stock ranged from 28.1 to $93.9 \mathrm{t} \mathrm{ha}^{-1}$ and from 0.6 to $8.7 \mathrm{tha}^{-1}$ with stand ages in trees and deadwoods, respectively. The proportion of shrubs, herbs, fine roots, litter, and deadwoods ranged from $0.1 \%-1 \%$ of the total ecosystem carbon, and was age-independent. Fine roots and deadwood which contribute to about $2 \%$ of the biomass carbon should be attached considerable weight in the investigation of natural forests. Soil carbon stock did not show a changing trend with stand age, ranging from 254.2 to $420.0 \mathrm{t} \mathrm{ha}^{-1}$ with an average of $358.7 \mathrm{t} \mathrm{ha}^{-1}$. The average value of carbon sequestration potential for these forests was estimated as $29.4 \mathrm{t} \mathrm{ha}^{-1}$, with the lower aged ones being the dominant contributor. The maximum carbon sequestration rate was $2.47 \mathrm{tha}^{-1}$ year-1 $^{-1}$ appearing in the growth stage of 37-56 years.

Conclusion The carbon stock in biomass was the major contributor to the increment of carbon stock in ecosystems. Stand age is not a good predictor of soil carbon stocks and accurate evaluation of the soil carbon dynamics thus requires long-term monitoring in situ. The results not only revealed carbon stock status and dynamics in these natural forests but were helpful to understand the role of Natural Forest Protection project in forest carbon sequestration as well. 


\section{Introduction}

The spruce forests are important communities in dark coniferous forests of the north temperate zone, and are a major forest type in northwestern China. Most of the forests are on high mountains with vertical distribution ranging elevations from $1200 \mathrm{~m}$ to $3800 \mathrm{~m}$. According to the 7th national forest inventory of China in 2008, spruce forests covered an area of approximately $3.94 \times 10^{6}$ ha and their stem volume was $9.9 \times 10^{8} \mathrm{~m}^{3}$ in the country (Chinese Ministry of Forestry 2010). As spruce forests generally have large carbon densities in their vegetation biomass and soil layers (Wagner et al. 2015; Zhou et al. 2000), there should be substantial amount of carbon storage and sequestration potential in these ecosystems. In the context of climate change, spruce forests are particularly important when assessing the carbon balance dynamics of high mountain forests.

Globally, a lot of work has been carried out to study allocation patterns and accumulation potential of carbon stock in forest ecosystems in the past few decades (Brown \& Lugo 1984; Dixon et al. 1994; Fang et al. 2001; Liu et al. 2014). However, considerable problems and uncertainties still exist in such studies. First, different methodologies may result in errors of carbon stock estimation. For example, as an important approach, the application of model simulation is limited by the assumption and applicable scope when estimating carbon stock in different ecosystems and the estimation error is difficult to measure (Piao et al. 2009; Preece et al. 2015; Quinkenstein \& Jochheim 2016). The method using a variable of Biomass Expansion Factor, another commonly applied method for estimating forest biomass, also has great error when up-scaling the carbon stock estimation from sample plot to a region (Fang et al. 2001; Sun et al. 2016). Secondly, carbon stock of tree layer in forests is commonly measured (Chen \& Luo 2015; Wang et al. 2014), but other components, such as understory vegetation (shrubs, herbs), litter, deadwoods, and fine roots have seldom been calculated because of costing much time and labor, although these components may contribute to considerable amounts of carbon stock and the cycling of forest ecosystems (Sun et al. 2015; Takahashi et al. 2010). Fine roots and deadwoods are active participants of carbon cycling and may play important roles in soil organic 
72

73

74

75

carbon accumulation. Fine roots are chiefly responsible for water and nutrient uptake into plants (Sun et al. 2015), and also are important sources of carbon in litter inputs within forest soils (Joslin et al. 2006; Leppalammi-Kujansuu et al. 2014). Deadwoods act as a carbon and nutrient reservoir (Chambers et al. 2000), and it could increase soil organic carbon sequestration in forest topsoil (Wambsganss et al. 2017). Finally, compared with the analyzed carbon content, the use of generalized coefficients $(0.5$ or 0.45$)$ for estimating carbon stock would lead to obvious error (Bhadwal \& Singh 2002; Fang et al. 2001; Lewis et al. 2009). Therefore, estimation based on comprehensive and exact surveys is needed to improve our understanding of carbon stock and sequestration potential in forest ecosystems.

Forest development has a close relationship with carbon stock over the entire life cycle of ecosystems, as tree growth rates vary greatly with stand age (Law et al. 2003; Taylor et al. 2007). Stand age is one of the critical factors in regulating carbon stock and the partitioning among different components such as the trees, litter, and soil (Fonseca et al. 2011; Law et al. 2003; Martin et al. 2005; Seedre et al. 2015). To our knowledge, however, most studies focused mainly on the dynamics of carbon stock in tree and soil while the carbon stock in understory (shrub, herb), litter, fine root and deadwood have seldom been considered. Meanwhile, the change of carbon accumulation along with stand age in soil (increase or stable) has been a controversial issue (Peichl \& Arain 2006; Zhao et al. 2014). It is thus necessary to explore the long-term changes of carbon accumulation and allocation in forest ecosystems.

Picea asperata and P. crassifolia are dominant conifer species and are also unique tree species in northwest China (Gou et al. 2005). This study took the two species as model to quantify the carbon accumulation and allocation among the various biomass components (tree, understory, litter, deadwood, fine root) and soil across an age sequence in northwest China. The overall goals were to: (1) estimate the carbon stock and allocation pattern of all ecosystem components, (2) assess the carbon accumulation potential. The information from this study is expected to provide more accurate evaluation of the carbon sequestration potential in dark coniferous forests, and also is crucial to evaluate spruce forest ecosystem services. 


\section{Materials and methods}

\subsection{Site description}

The study area (coverage coordinates $35^{\circ} 40^{\prime}-38^{\circ} 44^{\prime} \mathrm{N}$ and $99^{\circ} 49^{\prime}-106^{\circ} 17^{\prime} \mathrm{E}$ ) is located in Gansu and Ningxia provinces in northwest China (Figure 1). From 1981 to 2010, annually mean temperature ranged from 0.3 to $10.0{ }^{\circ} \mathrm{C}$ and mean annual precipitation ranged from 171.1 to 492 mm (National Meteorological Information Center 2012). Most of the rainfall occurs from July to September and the period of the highest temperature spans from June to August. Spruce forest is one of the major forest types in the two provinces and was protected after the Natural Forest Protection project (NFP) was launched in1998. P. asperata and P. crassifolia are dominant species, Populus davidiana, Salix caprea, S. rehderiana, and Betula utilis are the common companion species in tree layer, Elaeagnus pungens, Syringa oblata, Spiraea pubescens, Rosa multiflora, Potentilla fruticosa are dominant species in shrub layer, and Carex tristachya is the dominant species in herbaceous layer. The typical soil types are Dark-brown earths, Meadow sierozems and Cinnamon soils (National Soil Survey Office 1998).

\subsection{Sample plots establishment and sampling}

The sampling plan was implemented according to the method of scaling down: grid-siteplot, following the IPCC (2003). The specific method of establishing sample plots followed the guidance of Observation and Investigation for Carbon Sequestration in Terrestrial Ecosystems (Technical Manual Writing Group of Ecosystem Carbon Sequestration Project 2015). The number and location of sample plots of major communities were determined according to the weight of area, volume, distribution range, age class, which were referred from previous national forest surveys. Meanwhile, the forests with different age classes should be incorporated in the sample plots, so that the sample plots have the greatest representative significance for the forest type. According to the principles mentioned above, totally 39 representative sampling plots with the dimensions $20 \mathrm{~m} \times 50 \mathrm{~m}$ (several plots were slightly smaller depending on topography limitation) were established in spruce forests. These sampling plots are free from human interference and are distributed at an elevation range between 2300 and $3200 \mathrm{~m}$ a.s.1. Within 
126

127

128

129

130

131

132

133

134

135

136

137

138

139

140

141

142

143

144

145

146

147

148

149

150

151

152

each sampling plot, three representative shrub subplots with the dimensions $2 \mathrm{~m} \times 2 \mathrm{~m}$ were established along a diagonal of the sampling plot, while three subplots with dimensions $1 \mathrm{~m} \times 1$ $\mathrm{m}$ were set up along the other diagonal for sampling of herbage and litter. The sample survey was conducted between July and September 2012.

For each plot, tree height $(\mathrm{H})$ and diameter at breast height $(\mathrm{DBH})$ were measured for all Individuals with $\mathrm{DBH} \geq 2 \mathrm{~cm}$. Meanwhile, latitude, longitude, elevation, slope position, gradient and species names were recorded. Stand age for each plot was estimated by coring three biggest trees inside the plot. The average ring count of the tree samples is used as the stand age of each plot (Van Tuyl et al. 2005). Stand age of all sample plots ranged from 34 to 141 years and was divided into four age classes. The basic characteristics for the sample plots are summarized in Table 1.

For each dominant tree species, three to five sample trees with a small, medium and large DBH were selected for sampling to determine carbon content of tree components. Samples of stem, branch, needle, and root (about $300 \mathrm{~g}$ ) from each sample tree were collected and brought back to the laboratory for determining carbon content.

In each shrub and herb subplot, all aboveground organs were harvested, and the roots were excavated from the soil. The aboveground components of shrubs were further divided into leaves and branches. The fresh weight of each component was weighed in situ and subsamples were collected for determining carbon content and estimating dry biomass. Litter was collected and weighed in the field within the herbage subplots. Samples were also collected and brought back to laboratory for determining moisture and carbon content.

Downed dead trees were defined as those lying or leaning (with a zenith angle $\leq 45^{\circ}$ ) with mid-length diameter $\geq 2 \mathrm{~cm}$ and length $\geq 1 \mathrm{~m}$. Mid-length diameters and length of all downed dead trees were measured in each plot. Biomass was calculated using measured mid-length diameters, length and decomposition class specific density. Downed dead trees were divided into three grades according to the degree of decay: (1) mild decay, recently dead, some branches and foliage present; (2) moderate decay, there has been some loss of wood; (3) severe decay, there 
153 has been more loss of wood, and the wood is very fragile. One disc was collected from each

154

155

156

157

158 sampled dead wood to determine the density. At least 10 samples were collected from each tree species at each decomposition class (Technical Manual Writing Group of Ecosystem Carbon Sequestration Project 2015). The same carbon content value was assumed as for the live trees.

Standing dead trees (with a zenith angle $\geq 45$ and height $\geq 1.3 \mathrm{~m}$ ) were divided into two categories: one kind was leafless with almost complete crown and looked like live tree, the other kind was incomplete with fractured trunk or crown. Their biomass (including roots) were calculated differently. Biomass in the first kind of standing dead trees was calculated similarly to live trees (using allometric equations). Biomass in the latter kind was estimated by calculating their volume using a truncated cone formula and converted to biomass using the specific deadwood density (Technical Manual Writing Group of Ecosystem Carbon Sequestration Project 2015). Height of an individual was calculated using the height-diameter curves supplied by Zeng et al. (2009); and dead coarse root biomass was calculated similarly as for the first kind (mild decay) of standing dead trees. The same carbon content values were assumed as for the live trees to estimate the carbon stock of dead trees.

In each plot, ten representative core-samples were taken for soil down to a depth of $100 \mathrm{~cm}$ by the serpentine sampling method. Soil samples representing depths of $0-10 \mathrm{~cm}, 10-20 \mathrm{~cm}, 20$ $30 \mathrm{~cm}, 30-50 \mathrm{~cm}$, and $50-100 \mathrm{~cm}$ were collected using a soil sampling auger (4 $\mathrm{cm}$ diameter). Samples from the same depth layer in each plot were mixed for a more representative sample to measure the soil organic carbon content at that depth. In addition, a profile of $100 \mathrm{~cm}$-deep was dug and samples were extracted from five depth $(0-10,10-20,20-30,30-50$, and $50-100 \mathrm{~cm})$ using ring samplers to measure the soil bulk density.

While coarse roots (diameter $\geq 2 \mathrm{~mm}$ ) were included in the calculation by the methods of biomass equations and harvesting, sampling of fine roots was separately conducted. Soil coring technique was used to estimate fine root biomass, including live and dead roots that were less than $2.0 \mathrm{~mm}$ in diameter. Samples were randomly taken from ten points in each plot. A 4-cmdiameter steel auger was used to sample soil cores of depths in 0-20 and 20-40 cm. Samples 
180

181

182

183

184

185

186

187

188

189

190

191

192

193

194

195

196

197

198

199

200

201

202

203

204

were soaked in flowing water, rinsed and sieved out the roots, collected fine roots were reserved for determining biomass and carbon content.

\subsection{Determination of carbon content and calculation of carbon stock}

Biomass of each component (stem, branch, needle, and root) for trees was calculated through allometric biomass equations (Table 2) based on DBH and $\mathrm{H}$. Biomass equations were obtained from previous studies (Cheng et al. 2007; Forest Carbon Sequestration Project Office 2014). Biomass in shrub, herbage, and litter layer were determined by total harvesting approach mentioned above.

The plant and litter samples were oven dried at $70{ }^{\circ} \mathrm{C}$ until constant weight for calculating the biomass. Soil samples for determination of soil organic carbon content were air-dried and ground to pass through 2-mm sieve firstly to remove fine roots and other debris. Then, a part of screened soil was sampled through quartering and further ground until pass through $0.25 \mathrm{~mm}$ sieve prior to the laboratory analysis (National Agricultural Technology Extension Service Center 2006). The carbon content of plant, litter, and soil was analyzed using the traditional method of potassium dichromate oxidation-external heating.

The soil organic carbon stock $\left(\mathrm{t} \mathrm{ha}^{-1}\right)$ was calculated using the following equation:

$$
\mathrm{SOCS}=\sum_{\mathrm{m}=1}^{5} \mathrm{C}_{\mathrm{m}} \times \mathrm{BD}_{\mathrm{m}} \times \mathrm{D}_{\mathrm{m}} \times\left(1-\mathrm{G}_{\mathrm{m}}\right) / 10
$$

where $\mathrm{C}_{\mathrm{m}}$ is soil organic carbon content $\left(\mathrm{g} \mathrm{kg}^{-1}\right)$ in the soil layer $\mathrm{m}$ (totally five sampling layers in this study), $\mathrm{BD}_{\mathrm{m}}, \mathrm{D}_{\mathrm{m}}$, and $\mathrm{G}_{\mathrm{m}}$ are the bulk density $\left(\mathrm{g} \mathrm{cm}^{-3}\right)$, thickness $(\mathrm{cm})$, and the volumetric fraction of stones $(>2 \mathrm{~mm})$ in the corresponding soil layer, respectively.

Forest biomass carbon stock $\left(\mathrm{t} \mathrm{ha}^{-1}\right)$ was calculated as:

$$
B C S=\sum_{i=1}^{4}\left(G_{i} B_{t i}\right)+\sum_{j=1}^{3}\left(C_{s j} B_{s j}\right)+\sum_{k=1}^{2}\left(C_{h k} B_{h k}\right)+C_{m b} B_{w}+G B+G B
$$

where $\mathrm{i}$ represents the tree component (i.e., stem, branches, needles, and roots), $\mathrm{C}_{\mathrm{ti}}$ and $\mathrm{B}_{\mathrm{ti}}$ are the carbon content and biomass of the corresponding tree component, respectively; $\mathrm{j}$ is the shrub component (i.e., branches, leaves, and roots), $\mathrm{C}_{\mathrm{sj}}$ and $\mathrm{B}_{\mathrm{sj}}$ are the carbon content and biomass of 
205

206

207

208

209

210

211

212

213

214

215

216

217

218

219

220

221

222

223

224

225

226

227

228

229

230

231

the shrub component, respectively; $\mathrm{k}$ is the component of herbs (i.e., the aboveground and

belowground), $\mathrm{C}_{\mathrm{hk}}$ and $\mathrm{B}_{\mathrm{hk}}$ are the carbon content and biomass of the herb component, respectively; the other three items are carbon contents and biomass for deadwood, fine roots, and litter, respectively. Carbon stock and biomass follow the same unit of $\mathrm{t} \mathrm{ha}^{-1}$, while the carbon content should fall in a range of $0-1$. Total carbon stock in the ecosystem was the sum of those in biomass and soil.

\subsection{Calculation of the carbon accumulation potential and rates of stand biomass}

According the description concerning carbon sequestration potential reported by Keith et al. (2010) and Li \& Liu (2014), the carbon sequestration potential $\left(\mathrm{t} \mathrm{ha}^{-1}\right)$ of different stand age classes were calculated as:

$$
C S P_{n}=C C C-C C S_{n}
$$

where $\mathrm{n}$ is the stand age class ( $\mathrm{n}=\mathrm{I}, \mathrm{II}, \mathrm{II}, \mathrm{III}$, and IV), $\mathrm{CSP}_{\mathrm{n}}$ is carbon sequestration potential in age class $\mathrm{n}$; $\mathrm{CCC}$ is carbon carrying capacity of referred ecosystem, which is determined as the mean biomass carbon stock of three plots with the largest values; $\mathrm{CCS}_{\mathrm{n}}$ is the current biomass carbon stock of age class $n$, and it is the average value of biomass carbon stocks for all sample plots in the age class.

Carbon sequestration rate was estimated for three stages corresponding to the intervals of four age classes, i.e. I-II, II-III, and III-IV. The age intervals were determined by referring to the mean ages for the sample plots in corresponding classes as 21,14 , and 34 years for stages III (37-56 years), II-III (56-70 years), and III-IV (70-104 years), respectively. The difference in biomass carbon stocks between two age classes was divided by the age interval to give the carbon sequestration rate of a corresponding stage.

\subsection{Statistical analysis}

The effects of stand age on carbon stock in trees, understory, forest floor, soil, and the total ecosystem were tested using One-way ANOVA. All data were checked for normality and homogeneity of variances prior to One-way ANOVA and the results conformed to the normal distribution. Differences among the means of carbon stocks and carbon contents were 
232 determined with the LSD test at a significance level of $\mathrm{p}<0.05$. Exponential rise to maximum or 233 exponential decay models were used to express the relationships between carbon stock of each 234 component and stand age; the coefficient of determination $\left(\mathrm{R}^{2}\right)$ and the level of probability $(p)$

235 236

237

238 were used to determine the goodness of fitting. Statistical analyses were performed using SPSS 20.0 for windows (SPSS 20.0, SPSS Inc., USA).

\section{Results}

\subsection{Carbon stocks in trees, shrubs, and herbage}

Carbon stocks of tree components and the total tree layer increased with stand age (Table 3). Stems contributed the most part to the carbon stock of trees, and the contribution percentage ranged from $52.3 \%$ in age class I to $57.8 \%$ in age class IV. The average proportion of stem, branch, needle, and root relative to the total carbon stock in tree layer were $54.3 \%, 19.6 \%$, $10.8 \%$, and $15.3 \%$, respectively. The carbon stock in the total tree layer steadily increased along the age sequence, from $28.1 \mathrm{t} \mathrm{ha}^{-1}$ in age class I to $93.9 \mathrm{t} \mathrm{ha}^{-1}$ in age class IV.

Carbon stocks in shrub and herb layers varied from 0.14 to $1.26 \mathrm{t} \mathrm{ha}^{-1}$ and 0.27 to $1.8 \mathrm{t} \mathrm{ha}^{-1}$, respectively, and did not statistically different among the age classes (Table 4). The proportion in branches, leaves, and roots within the shrub layer were $41.38 \%, 6.90 \%$, and $51.72 \%$, respectively. In herb layer, aboveground and belowground accounted for $57.89 \%$ and $42.11 \%$, respectively. Carbon stocks in shrub and herb layers were independent of stand age $(p>0.05)$ based on regression analysis (Figure $2 \mathrm{a}$ and $\mathrm{b}$ ).

\subsection{Carbon stocks in soil}

Soil organic carbon content decreased significantly with increasing soil depth in all age classes (Table 5). The average soil organic carbon content decreased from $84.3 \mathrm{~g} \mathrm{~kg}^{-1}$ in $0-10 \mathrm{~cm}$ to $30.0 \mathrm{~g} \mathrm{~kg}^{-1}$ in $50-100 \mathrm{~cm}$. Soil organic carbon contents in $30-50$ and $50-100 \mathrm{~cm}$ showed statistically difference among age classes, whereas there was no significant variation with stand ages in upper soil layers.

Soil organic carbon stocks in 50-100 cm soil layers changed significantly with stand ages, but did not show a clear trend (Table 6). Those in other layers did not show significant difference 
259 among age classes. The soil organic carbon stored in deep soil (50-100 cm) contributed $26.4 \%$, $26045.7 \%, 39.6 \%$, and $25.2 \%$ to the total of $0-100 \mathrm{~cm}$ in age class I, II, III, and IV, respectively, 261 lower than that in the upper $50 \mathrm{~cm}$ layer. Soil carbon stock in the $0-100 \mathrm{~cm}$ ranged from 254.2 to $262420.0 \mathrm{t} \mathrm{ha}^{-1}$ and did not show a changing trend with stand age.

\section{3.3. Carbon stocks in the forest ecosystem}

264 The carbon stock in these forest ecosystems did not show significant variation with the age classes, ranging from 345.6 to $510.1 \mathrm{t} \mathrm{ha}^{-1}$ with an average of $449.4 \mathrm{t} \mathrm{ha}^{-1}$ (Table 7). Carbon stock in trees increased significantly with the increase in stand age whereas those in shrub and herb layers did not show a changing trend with stand age. Carbon stocks in fine roots and litter varied from 3.8 to $5.8 \mathrm{tha}^{-1}$ and from 1.5 to $11.7 \mathrm{t} \mathrm{ha}^{-1}$, accounting for $1-1.2 \%$ and $0.3-3.1 \%$ of the total ecosystem carbon stock, respectively. Carbon stock in deadwood increased from 0.6 to 8.6 tha $^{-1}$ with development of the forests with the proportion from $0.2 \%$ to $2.3 \%$. Soil was the largest contributor to the ecosystem carbon stock although the contribution decreased from $88.6 \%$ to $68.1 \%$ with the development of forests. The contribution of biomass carbon stock increased from $11.4 \%$ to $31.9 \%$ across the range of stand age-class and was significantly related to stand age $(p$ $<0.001$ ) according to regression analysis (Figure 2c).

\subsection{Vegetation carbon accumulation potentials and rate}

Carbon sequestration potential decreased with the development of the forests, from $76.8 \mathrm{tha}^{-}$

${ }^{1}$ in age class I to $5.3 \mathrm{t} \mathrm{ha}^{-1}$ in age class IV with an average of $29.4 \mathrm{t} \mathrm{ha}^{-1}$ (Figure 3a). The carbon sequestration rate decreased from $2.47 \mathrm{tha}^{-1}$ year-1 $^{-1}$ in the growth stage of 37-56 years to $0.15 \mathrm{t}$ $\mathrm{ha}^{-1}$ year $^{-1}$ in the growth stage of 70-104 years (Figure 3b).

\section{Discussion}

\subsection{Carbon allocation and dynamics in ecosystem components}

The proportion of carbon stock in various components of tree layer decreased in an order of stems $(54.3 \%)>$ branches $(19.6 \%)>\operatorname{roots}(15.3 \%)>$ needles $(10.8 \%)$ (Table 3$)$. Similar patterns were observed in P. crassifolia forests in the Qilian Mountains (Wagner et al. 2015). The proportion of carbon stock in stem increased with stand age whereas the proportion in roots of 
286 the tree layer decreased, suggesting that carbon allocation to the roots reduced with the increase 287 of stand age. Similar results were also observed in Pinus tabuliformis (Zhao et al. 2014), Pinus 288 strobus (Peichl \& Arain 2006), and several other forest types in northeast China (Wang et al. 289 2008). Such a trend can owed to the tree growth strategy that more resources was allocated to 290 roots in early stages of growth in order to maximize water and nutrient assimilation that support 291 survival (Helmisaari et al. 2002; Mund et al. 2002). With the development, productivity of tree 292 foliage biomass no longer increases, resulting in decreased demand for nutrient and water supply 293 from roots (Claus \& George 2005; Kurz et al. 1996; Vanninen et al. 1996).

The amount of carbon stored in tree components and total tree biomass increased rapidly with stand age, which was consistent with the results reported by Chen et al. (2016) and Guo \& Ren (2014). The contribution of carbon stock in trees to total ecosystem increased significantly, from $8.1 \%$ to $25.2 \%$ across the entire age sequence (Table 7 ), indicating that the tree layer could accumulate carbon constantly throughout the forest development. The increase of carbon stock in trees got slowly when stand age exceeds 60 years. Taylor et al. (2007) and Rothstein et al. (2004) also reported that this increasing trend could be described as a sigmoidal pattern, i.e. young forests displayed rapid growth up to a certain age following which time their growth rate decreased gradually. This phenomenon could be ascribe to possible hydraulic and nutrient limitations (Ryan et al. 1997; Yuan \& Chen 2012), rise of mortality resulted from tree ageing (Luo \& Chen 2011), competition and disturbance (e.g. insects, wind, and fungi) (Metslaid et al. 2007), and/or steeper declines in photosynthesis than in respiration (Tang et al. 2014). The and sequestering $\mathrm{CO}_{2}$ (Hou et al. 2015), but their carbon stocks account only about $0.1 \%$ and $0.3 \%$ of the total ecosystem, respectively (Table 7 ). There are studies suggesting that absence of increase of total ecosystem carbon stock across the entire age sequence was mainly contributed by the carbon stock in trees, which highlighted the importance of tree biomass carbon in forest ecosystem carbon estimates.

Understory vegetation (shrubs and herbs) play an important role in maintaining biodiversity the calculation for understory could lead to underestimation of carbon sequestration capacity 
313 (Gao et al. 2014; Park 2015). Previous studies found that carbon stock in the understory (shrubs 314 and herbs) decreased with the increase in stand age (Cao et al. 2012; Taylor et al. 2007). In this 315 study, however, the carbon stock in the understory did not show a clear changing trend with 316 stand age. The distinction in species ecological characteristics, light, and nutrients probably 317 contributed to this difference (Abdallah \& Chaieb 2012; Arx et al. 2012). Our results showed 318 that the carbon stocks in shrub and herb layers were independent of stand age.

As a significant component affecting carbon transfer from vegetation biomass to soil, carbon stock in litter ranged from 1.5 to $11.7 \mathrm{t} \mathrm{ha}^{-1}$ with the average value of $4.5 \mathrm{t} \mathrm{ha}^{-1}$ in this study, which was comparable with the average value $\left(2.8 \mathrm{tha}^{-1}\right)$ of $P$. crassifolia forests in the Qilian Mountains (Wagner et al. 2015). Similar climate and tree species should be responsible for the result. However, the litter carbon stock in this study was less than the average of major forest types in China (8.21 tha-1) (Zhou et al. 2000). This can be attributed to the influence of species, stand age, and climate (Jiang et al. 2013; Takahashi et al. 2010). Carbon stock in litter layer showed different trends (increase or decrease) with stand age (Seedre et al. 2015; Zhao et al. 2014). Unlike previous results, carbon stock in litter layer showed no regular trend with stand age in this study. Generally, carbon stock in litter layer is determined by the net balance between litter fall input and decomposition output, thus any factors affecting the amount of input and decomposition rate would affect the carbon storage of litter.

In this study, carbon stocks in fine roots and deadwoods roughly accounted for $1.0 \%$ and $0.8 \%$ of total carbon stock in the whole ecosystem, respectively (Table 7). Exclusion from forest carbon stock estimation, which is commonly dealt with, may result in underestimation of total ecosystem carbon stock. Therefore, it is recommended that fine root and deadwood mass be calculated in such studies as natural forests. Carbon stock in deadwood increased with the increase in stand age. Similar trend was reported for Norway spruce ecosystem (Seedre et al. 2015), showing significant correlation between the dead biomass carbon and stand age. The high mortality of trees in old forests and relatively slow decomposition caused by low temperature should be responsible for the phenomenon in the areas. Fine root carbon stock in this study had 
340

341

342

343

344

345

346

347

348

349

350

351

352

353

354

355

356

357

358

359

360

361

362

363

364

365

366

no significant changing trend among age classes, which was inconsistent with that found in $B$. platyphylla (Sun et al. 2015) and Scots pine (Makkonen \& Helmisaari 2001). This difference may be partly ascribed to the differences in species composition and/or environmental conditions (Leuschner et al. 2007).

The spruce forests have substantial soil organic carbon stock. The average amount in 0-100 $\mathrm{cm}$ is $358.7 \mathrm{t} \mathrm{ha}^{-1}$ in this study which is close to the results reported by previous relative studies. For example, Zhou et al. (2000) found that soil organic carbon stock in Picea-Abies forests in China was $360.8 \mathrm{t} \mathrm{ha}^{-1}$, and Wagner et al. (2015) found that soil organic carbon stock in $P$. crassifolia forest in the Qilian Mountains was $305.0 \mathrm{t} \mathrm{ha}^{-1}$. Meanwhile, these results are greater than that reported for Norway spruce forest $\left(130.0 \mathrm{t} \mathrm{ha}^{-1}\right)$ (Seedre et al. 2015) and an averaged amount for major forest types in China $\left(193.6 \mathrm{t} \mathrm{ha}^{-1}\right)$ (Zhou et al. 2000). The high soil organic carbon stock in spruce forests in northwest China is probably resulted from the low soil temperatures in combination with low soil moisture, which not only inhibited soil biological activity in large part of the growing season (Zheng et al. 2014), but also reduced the respiration rate and thus lowered the decomposition activity in soil (Rotenberg \& Yakir 2010; Wagner et al. 2015). The annually mean temperature and mean annual precipitation in our study area are all less than that in Norway spruce forest (Seedre et al. 2015). Callesen et al. (2003) and Perruchoud et al. (2000) also suggested that high soil organic carbon stock was often associated with low temperature and low soil moisture.

The average proportion of soil carbon stock in ecosystems of all stand age classes is $79.8 \%$ in this study (Table 7). This proportion is close to the results for Picea-Abies forests previously reported (77.8\%) (Zhou et al. 2000) and is higher than the global average value (approximately 69\%) (Dixon et al. 1994). Meanwhile, this proportion is also much higher than the proportion for tropical forests (32\%) reported by Pan et al. (2011), which was ascribed to the higher productivity of tree layer in tropical forests (Lü et al. 2010). The ratio of soil organic carbon stock to biomass carbon stock decreased from 8.7 to 2.4 with increasing stand age, which was consistent with boreal and temperate forests in northeastern China (Wei et al. 2013). The 
367

368

369

370

371

372

373

374

375

376

377

378

379

380

381

382

383

384

385

386

387

388

389

390

391

392

393

potential cause of the decline pattern might be the increasing trend of carbon stock in tree layer coupled with relatively stable carbon stock in soil layer along with the forest development.

Stand age is not a good predictor of soil organic carbon stock. Soil organic carbon stock did not change significantly with the increase of forest age in this study (Table 7), which was consistent with the conclusion by Marín-Spiotta et al. (2013) found in successional and plantation forests. Lal (2004) and Martin et al. (2005) also proposed that soil organic carbon stock remains stable in place over years to centuries. One explanation was the formation of soil carbon needs a relatively long time, which is primarily controlled by three stabilization mechanisms: chemical stabilization, physical protection, and biochemical stabilization (Six et al. 2002; Sollins et al. 1996; von Lutzow et al. 2006). This means that soil organic carbon stock may not be sensitive to the development of forests. Wang et al. (2016b) reported that soil organic carbon accumulation showed a time lag about 15-30 years compared to forest development in natural restoration. Additionally, many studies demonstrated there were other variation trends between stand age and soil organic carbon stock in forest ecosystem. For instance, Eaton \& Lawrence (2009) found soil organic carbon stock was higher in the youngest and oldest natural secondary forests and was lower in sites of intermediate age in the southern Yucatán Peninsula. Nevertheless, the study of Wang et al. (2016b) found an initial decrease and subsequent increase trend of soil carbon stock with natural restoration chronosequence on the Loess Plateau of China. Zhou et al. (2006) found the soil carbon stock continued increasing even in an old-growth forest. Finally, studies also suggest that soil organic carbon stocks in forests can be influenced by climate, soil texture, soil thickness, and tree species (Peichl \& Arain 2006; Seedre et al. 2015; Yang et al. 2008). Especially, Marín-Spiotta et al. (2013) believed that climate could explain the greater variability in soil organic carbon stock in tropical forests than stand age. Overall, the mechanism behind the relationship between soil organic carbon accumulation and forest age needs further clarification.

The average value of ecosystem carbon stock in this study was $449.4 \mathrm{t} \mathrm{ha}^{-1}$ (Table 7), which was much more than other reports for natural secondary forest in northwest China $\left(160 \mathrm{t} \mathrm{ha}^{-1}\right)$ 
394 (Houghton \& Hackler 2003) and major forest types in China (258.8 t ha-1) (Zhou et al. 2000).

395 Meanwhile, our result was also higher than the reports for P. crassifolia forest $\left(348 \mathrm{t} \mathrm{ha}^{-1}\right)$

396 (Wagner et al. 2015) and Norway spruce (393 $\left.\mathrm{t} \mathrm{ha}^{-1}\right)$ (Seedre et al. 2015). Besides forest types

397 and age structure, climate and edaphic factors may be responsible for such differences. Our study

398 reconfirmed that spruce forests have substantial carbon stock.

399 Ecosystem carbon stock in this study had no significant variation with the increase of stand 400 age (Table 7). The different variation pattern from Wang et al. (2016b) probably reflects the 401 distinction of carbon sequestration ability of different tree species. The dominant tree species

402 were Quercus liaotungensis, P. davidiana, and B. platyphylla in the study of Wang et al.

403 (2016b). This may help us understand the spatial and temporal heterogeneity of carbon

404 sequestration characteristics of different dominant tree species.

405

406

407

408

409

410

411

412

413

414

415

416

417

418

419

420

\subsection{Carbon sequestration potentials in the forest biomass}

Estimating the carbon sequestration potential in natural forest ecosystems is the basis of predicting long-term changes of carbon dynamics. The average value of carbon sequestration potential by the vegetation biomass was estimated as $29.4 \mathrm{tha}^{-1}$ in these natural spruce forests, which fell in the range (12.27-49.88 $\left.\mathrm{t} \mathrm{ha}^{-1}\right)$ found in alpine forests in Qinghai-Xizang Plateau (Wang et al. 2016a). Meanwhile, these estimates were much less than the result reported by Zhong et al. (2014) for natural forests in Karst area (57.88 $\left.\mathrm{t} \mathrm{ha}^{-1}\right)$. The land-use history (Roxburgh et al. 2006), climate, and age structure (Liu et al. 2014) are important factors affecting forest carbon sequestration potential in different study areas. Spruce forests in northwest China suffered some disturbances before implementing the NFP, resulting in lack of enough old stands. The low aged forests are the dominant contributor of carbon sequestration potential in the natural spruce forests in northwest China.

Carbon sequestration rate in these forests ranged from 0.15 to $2.47 \mathrm{t} \mathrm{ha}^{-1} \mathrm{year}^{-1}$, which was less than the estimate of aboveground biomass for dominant tree species in a tropical deciduous forest (1.47-4.64 $\mathrm{t} \mathrm{ha}^{-1}$ year-1) (Devi \& Yadava 2015). However, the maximum carbon sequestration rate $\left(2.47 \mathrm{t} \mathrm{ha}^{-1}\right.$ year-1 $\left.^{-1}\right)$ in this study was greater than the estimate of $0.95 \mathrm{t} \mathrm{ha}^{-1}$ 
421 year ${ }^{-1}$ for broad-leaved mature forests in Qinghai-Xizang Plateau (Wang et al. 2016a), and was

422 also greater than that for temperate forests in northwest China $\left(1.1 \mathrm{t} \mathrm{ha}^{-1}\right.$ year $\left.^{-1}\right)$ (Houghton \&

423 Hackler 2003). These observed differences in the carbon sequestration rate may be related to

424 species composition, growth stage, and climatic factors (Devi \& Yadava 2015). Quantifying

425 carbon sequestration rate across stand age gradient is expected to provide more accurate

426 assessments of the potential increment of vegetation carbon accumulation in forests.

427 The spruce forests in this study were located in the areas of NFP, and the estimation of

428 carbon sequestration potential and carbon sequestration rate was based on the premise of the

429 forests being under the protection in the future. Forests under NFP have covered $45 \%$ of the total

430 forest area in China and play a crucial role in regulating forest carbon sequestration (Chinese

431 Ministry of Forestry 2010). By 2020, carbon stock of forests under NFP is expected to increase

432 by $4 \times 10^{9} \mathrm{t}$ (Yang 2017). The NFP has acted its positive role in carbon accumulation in forests as

433 shown by the national forest inventory data (Hu \& liu 2006; Ke et al. 2015; Yang 2017; Zhou et

434 al. 2014). Our results highlighted the important role of NPF on carbon accumulation in forest

435 ecosystems.

436 5. Conclusions

437 Carbon partitioning in all ecosystem components (vegetation biomass, deadwood, litter, and 438 soil) across age classes were comprehensively estimated in natural spruce forests in northwest 439 China. Tree layer could accumulate carbon constantly with the development of forest. Shrub, 440 herb, and litter layers accounted for about $0.1 \%-1 \%$ of the total ecosystem carbon and were age441 independent. Fine roots and deadwoods also play important roles in carbon accumulation, 442 accounting for approximately $1.0 \%$ and $0.8 \%$ of ecosystem carbon stock, respectively. In each 443 age class, the soil contributed more than $65 \%$ of the ecosystem carbon stock. Stand age is not a 444 good predictor of soil carbon stock. Hence, accurate evaluation of the soil organic carbon stock 445 dynamics in the forests requires long-term monitoring in situ. The carbon stock in biomass was 446 the major contributor to the increment of carbon stock in ecosystems. The average value of 447 carbon sequestration potential for these forests was estimated as $29.4 \mathrm{t} \mathrm{ha}^{-1}$, with the lower aged 
448 ones being the dominant contributor. The maximum carbon sequestration rate was $2.47 \mathrm{t} \mathrm{ha}^{-1}$

449 year $^{-1}$ appearing in the growth stage of 37-56 years. The information from this study will

450 improve our understanding of carbon stocks and dynamics in natural forests and can be helpful

451 to evaluating the role of NFP in increasing forest carbon accumulation.

452 Acknowledgments: We gratefully acknowledge many other members (graduate and

453 undergraduate students) from Northwest A\&F University contributing to the field investigation.

454

\section{References}

456 Abdallah F, and Chaieb M. 2012. The influence of trees on nutrients, water, light availability and understorey vegetation in an arid environment. Applied Vegetation Science 15:501-512. 10.1111/j.1654109X.2012.01201.x

Chambers JQ, Higuchi N, Schimel JP, Ferreira LV, and Melack JM. 2000. Decomposition and carbon cycling of dead

Arx GV, Dobbertin M, and Rebetez M. 2012. Spatio-temporal effects of forest canopy on understory microclimate in a long-term experiment in Switzerland. Agricultural and Forest Meteorology 166:144-155. 10.1016/j.agrformet.2012.07.018

Bhadwal S, and Singh R. 2002. Carbon sequestration estimates for forestry options under different land-use scenarios in India. Current Science 83:1380-1386.

Brown S, and Lugo AE. 1984. Biomass of tropical forests: a new estimate based on forest volumes. Science 223:12901293. $10.1126 /$ science. 223.4642 .1290

Callesen I, Liski J, Raulund-Rasmussen K, Olsson MT, Tau-Strand L, Vesterdal L, and Westman CJ. 2003. Soil carbon stores in Nordic well-drained forest soils - relationships with climate and texture class. Global Change Biology 9:358-370. 10.1046/j.1365-2486.2003.00587.x

Cao JX, Wang XP, Tian Y, Wen ZY, and Zha TS. 2012. Pattern of carbon allocation across three different stages of stand development of a Chinese pine (Pinus tabulaeformis) forest. Ecological Research 27:883-892. $10.1007 / \mathrm{s} 11284-012-0965-1$ trees in tropical forests of the central Amazon. Oecologia 122:380-388. 10.1007/s004420050044

Chen HY, and Luo Y. 2015. Net aboveground biomass declines of four major forest types with forest ageing and 
477 Chen LC, Liang MJ, and Wang SL. 2016. Carbon stock density in planted versus natural Pinus massoniana forests in sub-tropical China. Annals of Forest Science 73:461-472. 10.1007/s13595-016-0539-4

Cheng T, Ma Q, Feng Z, and Luo X. 2007. Research on forest biomass in Xiaolong Mountains, Gansu province. Journal of Beijing Forestry University 29:31-36.

Chinese Ministry of Forestry. 2010. Forest Resource Statistics of China (2004-2008). Beijing: China Forestry Publishing House.

483

484

Claus A, and George E. 2005. Effect of stand age on fine-root biomass and biomass distribution in three European forest chronosequences. Canadian Journal of Forest Research 35:1617-1625. 10.1139/x05-079

Devi LS, and Yadava PS. 2015. Carbon stock and rate of carbon sequestration in Dipterocarpus forests of Manipur, Northeast India. Journal of Forestry Research 26:315-322. 10.1007/s11676-015-0070-8

Dixon RK, Solomon AM, Brown S, Houghton RA, Trexier MC, and Wisniewski J. 1994. Carbon pools and flux of global forest ecosystems. Science 263: 185-190.

Eaton JM, and Lawrence D. 2009. Loss of carbon sequestration potential after several decades of shifting cultivation in the Southern Yucatan. Forest Ecology and Management 258:949-958. 10.1016/j.foreco.2008.10.019

Fang JY, Chen AP, Peng CH, Zhao SQ, and Ci L. 2001. Changes in forest biomass carbon storage in China between 1949 and 1998. Science 291:2320-2322.

Fonseca W, Rey Benayas JM, and Alice FE. 2011. Carbon accumulation in the biomass and soil of different aged secondary forests in the humid tropics of Costa Rica. Forest Ecology and Management 262:1400-1408. 10.1016/j.foreco.2011.06.036

Forest Carbon Sequestration Project Office. 2014. Current Carbon Storage, Rate, Mechanism and Potential of Forest Ecosystems in China-Biomass Equation 1st edn. unpublished.

Gao Y, Cheng JM, Ma ZR, Zhao Y, and Su JS. 2014. Carbon storage in biomass, litter, and soil of different plantations in a semiarid temperate region of northwest China. Annals of Forest Science 71:427-435. 10.1007/s13595$013-0355-\mathrm{z}$

Gou X, Chen F, Yang M, Li J, Peng J, and Jin L. 2005. Climatic response of thick leaf spruce (Picea crassifolia) tree- 
502

503

504

505

506

507

508

509

510

511

512

513

514

515

516

517

518

519

520

521

522

523

524

525

526

527

528

ring width at different elevations over Qilian Mountains, northwestern China. Journal of Arid Environments $61: 513-524$

Guo QF, and Ren H. 2014. Productivity as related to diversity and age in planted versus natural forests. Global Ecology and Biogeography 23:1461-1471. 10.1111/geb.12238

Helmisaari HS, Makkonen K, Kellomaki S, Valtonen E, and Malkonen E. 2002. Below- and above-ground biomass, production and nitrogen use in scots pine stands in eastern Finland. Forest Ecology and Management 165:317-326. 10.1016/s0378-1127(01)00648-X

Hou L, Xi WM, and Zhang SX. 2015. Effect of understory on a natural secondary forest ecosystem carbon budget. Russian Journal of Ecology 46:51-58. 10.1134/s1067413615010099

Houghton RA, and Hackler JL. 2003. Sources and sinks of carbon from land-use change in China. Global Biogeochemical Cycles 17:1-19. 10.1029/2002gb001970

Hu HF, and liu GH. 2006. Carbon sequestration of China' s National Natural Forest Protection Project. Acta Ecologica Sinica:291-296.

IPCC. 2003. Good practice guidance for land use, land-use change and forestry (ed. by Penman, J., Gytarsky, M., Hiraishi, T., Krug, T., Kruger, D., Pipatti, R., Buendia, L., Miwa, K., Ngara, T., Tanabe, K., and Wagner, F.). Kanagawa, Japan: Institute for Global Environmental Strategies

Jiang J, Li YK, Wang MZ, Zhou CP, Cao GM, Shi PL, and Song MH. 2013. Litter species traits, but not richness, contribute to carbon and nitrogen dynamics in an alpine meadow on the Tibetan Plateau. Plant and Soil 373:931-941. 10.1007/s11104-013-1859-x

Joslin JD, Gaudinski JB, Torn MS, Riley WJ, and Hanson PJ. 2006. Fine-root turnover patterns and their relationship to root diameter and soil depth in a ${ }^{14}$ C-labeled hardwood forest. New Phytologist 172:523-535. 10.1111/j.1469-8137.2006.01847.x

Ke SF, Chen ZC, Robson M, Wen YL, and Tian XH. 2015. Evaluating the implementation efficiency of the Natural Forest Protection Program in ten provinces of western China by using Data Envelopment Analysis (DEA). International Forestry Review 17:469-476.

Keith H, Mackey B, Berry S, Lindenmayer D, and Gibbons P. 2010. Estimating carbon carrying capacity in natural forest ecosystems across heterogeneous landscapes: addressing sources of error. Global Change Biology 
Kurz WA, Beukema SJ, and Apps MJ. 1996. Estimation of root biomass and dynamics for the carbon budget model of the Canadian forest sector. Canadian Journal of Forest Research 26:1973-1979. 10.1139/x26-223

532

Lü XT, Yin JX, Jepsen MR, and Tang JW. 2010. Ecosystem carbon storage and partitioning in a tropical seasonal forest in Southwestern China. Forest Ecology and Management 260:1798-1803. 10.1016/j.foreco.2010.08.024

Lal R. 2004. Soil carbon sequestration impacts on global climate change and food security. Science 304:1623-1627. 10.1126/science. 1097396

Law BE, Sun OJ, Campbell J, Van Tuyl S, and Thornton PE. 2003. Changes in carbon storage and fluxes in a chronosequence of ponderosa pine. Global Change Biology 9:510-524. 10.1046/j.1365-2486.2003.00624.x

Leppalammi-Kujansuu J, Aro L, Salemaa M, Hansson K, Kleja DB, and Helmisaari H-S. 2014. Fine root longevity and carbon input into soil from below- and aboveground litter in climatically contrasting forests. Forest Ecology and Management 326:79-90. 10.1016/j.foreco.2014.03.039

Leuschner C, Moser G, Bertsch C, Röderstein M, and Hertel D. 2007. Large altitudinal increase in tree root/shoot ratio in tropical mountain forests of Ecuador. Basic and Applied Ecology 8:219-230. 10.1016/j.baae.2006.02.004

Lewis SL, Lopez-Gonzalez G, Sonke B, Affum-Baffoe K, Baker TR, Ojo LO, Phillips OL, Reitsma JM, White L, Comiskey JA, Djuikouo K M-N, Ewango CEN, Feldpausch TR, Hamilton AC, Gloor M, Hart T, Hladik A, Lloyd J, Lovett JC, Makana J-R, Malhi Y, Mbago FM, Ndangalasi HJ, Peacock J, Peh KSH, Sheil D, Sunderland T, Swaine MD, Taplin J, Taylor D, Thomas SC, Votere R, and Woell H. 2009. Increasing carbon storage in intact African tropical forests. Nature 457:1003-1007. 10.1038/nature07771

Li T, and Liu G. 2014. Age-related changes of carbon accumulation and allocation in plants and soil of black locust forest on Loess Plateau in Ansai County, Shaanxi Province of China. Chinese Geographical Science 24:414422. $10.1007 / \mathrm{s} 11769-014-0704-3$

Liu YC, Yu GR, Wang QF, and Zhang YJ. 2014. How temperature, precipitation and stand age control the biomass carbon density of global mature forests. Global Ecology and Biogeography 23:323-333. 10.1111/geb.12113

Luo Y, and Chen HYH. 2011. Competition, species interaction and ageing control tree mortality in boreal forests. 
557 Makkonen K, and Helmisaari HS. 2001. Fine root biomass and production in Scots pine stands in relation to stand age. Tree Physiology 21:193-198.

559

560

Marín-Spiotta E, Sharma S, and Ramankutty N. 2013. Carbon storage in successional and plantation forest soils: a tropical analysis. Global Ecology and Biogeography 22:105-117. 10.1111/j.1466-8238.2012.00788.x

Martin JL, Gower ST, Plaut J, and Holmes B. 2005. Carbon pools in a boreal mixedwood logging chronosequence. Global Change Biology 11:1883-1894. 10.1111/j.1365-2486.2005.01019.x

Metslaid M, Jogiste K, Nikinmaa E, Moser WK, and Porcar-Castell A. 2007. Tree variables related to growth response and acclimation of advance regeneration of Norway spruce and other coniferous species after release. Forest Ecology and Management 250:56-63. 10.1016/j.foreco.2007.03.009

Mund M, Kummetz E, Hein M, Bauer GA, and Schulze ED. 2002. Growth and carbon stocks of a spruce forest chronosequence in central Europe. Forest Ecology and Management 171:275-296. 10.1016/s0378$1127(01) 00788-5$

National Agricultural Technology Extension Service Center. 2006. Technical Specification For Soil Analysis (Second Edition). Beijing: Chinese agriculture press.

National Meteorological Information Center. 2012. Chinese ground annually mean value datasets (1981-2010) Available at http://data.cma.ch/data/detail/dataCode/A.0029.0005.html (accessed June 4, 2016.

National Soil Survey Office. 1998. Chinese soil. Beijing: China Agriculture Press.

Pan Y, Birdsey RA, Fang J, Houghton R, Kauppi PE, Kurz WA, Phillips OL, Shvidenko A, Lewis SL, Canadell JG, Ciais P, Jackson RB, Pacala SW, McGuire AD, Piao S, Rautiainen A, Sitch S, and Hayes D. 2011. A large and persistent carbon sink in the world's forests. Science 333:988-993. 10.1126/science.1201609

Park A. 2015. Carbon storage and stand conversion in a pine-dominated boreal forest landscape. Forest Ecology and Management 340:70-81. 10.1016/j.foreco.2014.12.011

Peichl M, and Arain MA. 2006. Above- and belowground ecosystem biomass and carbon pools in an age-sequence of temperate pine plantation forests. Agricultural and Forest Meteorology 140:51-63. 10.1016/j.agrformet.2006.08.004

Perruchoud D, Walthert L, Zimmermann S, and Luscher P. 2000. Contemporary carbon stocks of mineral forest soils 
in the Swiss Alps. Biogeochemistry 50:111-136. 10.1023/a:1006320129112

584

585

586

587

588

589

590

591

592

593

594

595

596

597

598

599

600

601

602

603

604

605

606

607

608

609

Piao SL, Fang JY, Ciais P, Peylin P, Huang Y, Sitch S, and Wang T. 2009. The carbon balance of terrestrial ecosystems in China. Nature 458:1009-1013. 10.1038/nature07944

Preece ND, Lawes MJ, Rossman AK, Curran TJ, and van Oosterzee P. 2015. Modelling the growth of young rainforest trees for biomass estimates and carbon sequestration accounting. Forest Ecology and Management 351:5766. 10.1016/j.foreco.2015.05.003

Quinkenstein A, and Jochheim H. 2016. Assessing the carbon sequestration potential of poplar and black locust short rotation coppices on mine reclamation sites in Eastern Germany-Model development and application. Journal of Environment Management 168:53-66. 10.1016/j.jenvman.2015.11.044

Rotenberg E, and Yakir D. 2010. Contribution of Semi-Arid Forests to the Climate System. Science 327:451-454. 10.1126/science.1179998

Rothstein DE, Yermakov ZY, and Buell AL. 2004. Loss and recovery of ecosystem carbon pools following standreplacing wildfire in Michigan jack pine forests. Canadian Journal of Forest Research 34:1908-1918. $10.1139 / \mathrm{x} 04-063$

Roxburgh SH, Wood SW, Mackey BG, Woldendorp G, and Gibbons P. 2006. Assessing the carbon sequestration potential of managed forests: a case study from temperate Australia. Journal of Applied Ecology 43:11491159. $10.1111 /$ j.1365-2664.2006.01221.x

Ryan MG, Binkley D, and Fownes JH. 1997. Age-related decline in forest productivity: pattern and process. Advances in Ecological Research 27:213-262. 10.1016/s0065-2504(08)60009-4

Seedre M, Kopáček J, Janda P, Bače R, and Svoboda M. 2015. Carbon pools in a montane old-growth Norway spruce ecosystem in Bohemian Forest: effects of stand age and elevation. Forest Ecology and Management 346:106113. 10.1016/j.foreco.2015.02.034

Six J, Conant RT, Paul EA, and Paustian K. 2002. Stabilization mechanisms of soil organic matter: Implications for C-saturation of soils. Plant and Soil 241:155-176. 10.1023/a:1016125726789

Sollins P, Homann P, and Caldwell BA. 1996. Stabilization and destabilization of soil organic matter: Mechanisms and controls. Geoderma 74:65-105. 10.1016/s0016-7061(96)00036-5

Sun Qf, Jia LM, Han LD, and Liu BF. 2016. Research progress of forest vegetation and soil carbon storage in China. 
611 Sun T, Dong LL, Mao ZJ, and Li YY. 2015. Fine root dynamics of trees and understorey vegetation in a chronosequence of Betula platyphylla stands. Forest Ecology and Management 346:1-9. 10.1016/j.foreco.2015.02.035

Takahashi M, Ishizuka S, Ugawa S, Sakai Y, Sakai H, Ono K, Hashimoto S, Matsuura Y, and Morisada K. 2010. Carbon stock in litter, deadwood and soil in Japan's forest sector and its comparison with carbon stock in agricultural soils. Soil Science and Plant Nutrition 56:19-30. 10.1111/j.1747-0765.2009.00425.x

Tang JW, Luyssaert S, Richardson AD, Kutsch W, and Janssens IA. 2014. Steeper declines in forest photosynthesis than respiration explain age-driven decreases in forest growth. Proceedings of the National Academy of Sciences of the United States of America 111:8856-8860. 10.1073/pnas.1320761111

Taylor AR, Wang JR, and Chen HYH. 2007. Carbon storage in a chronosequence of red spruce (Picea rubens) forests in central Nova Scotia, Canada. Canadian Journal of Forest Research 37:2260-2269. 10.1139/x07-080

Technical Manual Writing Group of Ecosystem Carbon Sequestration Project. 2015. Observation and Investigation for Carbon Sequestration in Terrestrial Ecosystems. Beijing: Science Press.

Van Tuyl S, Law BE, Turner DP, and Gitelman AI. 2005. Variability in net primary production and carbon storage in biomass across oregon forests-an assessment integrating data from forest inventories, intensive sites, and remote sensing. Forest Ecology and Management 209:273-291. 10.1016/j.foreco.2005.02.002

Vanninen P, Ylitalo H, Sievanen R, and Makela A. 1996. Effects of age and site quality on the distribution of biomass in Scots pine (Pinus sylvestris L.). Trees 10:231-238. 10.1007/bf02185674

von Lutzow M, Kogel-Knabner I, Ekschmitt K, Matzner E, Guggenberger G, Marschner B, and Flessa H. 2006. Stabilization of organic matter in temperate soils: mechanisms and their relevance under different soil conditions - a review. European Journal of Soil Science 57:426-445. 10.1111/j.1365-2389.2006.00809.x

Wagner B, Liang EY, Li XX, Dulamsuren C, Leuschner C, and Hauck M. 2015. Carbon pools of semi-arid Picea crassifolia forests in the Qilian Mountains (north-eastern Tibetan Plateau). Forest Ecology and Management 343:136-143. 10.1016/j.foreco.2015.02.001

Wambsganss J, Stutz KP, and Lang F. 2017. European beech deadwood can increase soil organic carbon sequestration in forest topsoils. Forest Ecology and Management 405:200-209. 10.1016/j.foreco.2017.08.053 
637 Wang GX, Ran F, Chang RY, Yang Y, Luo J, and Fan JL. 2014. Variations in the live biomass and carbon pools of

638

639

640

641

642

643

644

645

646

647

648

649

650

651

652

653

654

655

656

657

658

659

660

661

662

663

Abies georgei along an elevation gradient on the Tibetan Plateau, China. Forest Ecology and Management 329:255-263. 10.1016/j.foreco.2014.06.023

Wang J, Wang GX, Wang CT, Ran F, and Chang RY. 2016a. Carbon storage and potentials of the broad-leaved forest in alpine region of the Qinghai-Xizang Plateau, China. Chinese Journal of Plant Ecology 40:374-384

Wang KB, Deng L, Ren ZP, Shi WY, Chen YP, and Shang-Guan ZP. 2016b. Dynamics of ecosystem carbon stocks during vegetation restoration on the Loess Plateau of China. Journal of Arid Land 8:207-220. $10.1007 / \mathrm{s} 40333-015-0091-3$

Wang XP, Fang JY, and Zhu B. 2008. Forest biomass and root-shoot allocation in northeast China. Forest Ecology and Management 255:4007-4020. 10.1016/j.foreco.2008.03.055

Wei YW, Li MH, Chen H, Lewis BJ, Yu DP, Zhou L, Zhou WM, Fang XM, Zhao W, and Dai LM. 2013. Variation in carbon storage and its distribution by stand age and forest type in boreal and temperate forests in northeastern China. PLoS One 8:1-9. 10.1371/journal.pone.0072201

Yang H. 2017. China's natural forest protection program: progress and impacts. Forestry Chronicle 93:113-117. $10.5558 / \mathrm{tfc} 2017-017$

Yang YH, Fang JY, Tang YH, Ji CJ, Zheng CY, He JS, and Zhu B. 2008. Storage, patterns and controls of soil organic carbon in the Tibetan grasslands. Global Change Biology 14:1592-1599. 10.1111/j.1365-2486.2008.01591.x

Yuan ZY, and Chen HYH. 2012. Fine root dynamics with stand development in the boreal forest. Functional Ecology 26:991-998. 10.1111/j.1365-2435.2012.02007.x

Zeng C, Lei XD, Liu XZ, Zhao LW, and Yang YJ. 2009. Individual tree height-diameter curves of larch-spruce-fir forests. Forest research 22:182-189.

Zhao JL, Kang FF, Wang LX, Yu XW, Zhao WH, Song XS, Zhang YL, Chen F, Sun Y, He TF, and Han HR. 2014. Patterns of biomass and carbon distribution across a chronosequence of Chinese pine (Pinus tabulaeformis) forests. PLoS One 9:1-12. 10.1371/journal.pone.0094966

Zheng XL, Zhao CY, Peng SZ, Jian SQ, Liang B, Wang XP, Yang SF, Wang C, Peng HH, and Wang Y. 2014. Soil $\mathrm{CO}_{2}$ efflux along an elevation gradient in Qinghai spruce forests in the upper reaches of the Heihe River, northwest China. Environmental Earth Sciences 71:2065-2076. 10.1007/s12665-013-2608-4

Peer] reviewing PDF | (2018:01:23461:1:1:NEW 9 Apr 2018) 
664 Zhong YX, Zhou YC, and Li ZJ. 2014. Research on the carbon storage and potential carbon sequestration of vegetation 665 in the trough valley of a Karst area, Yinjiang. Earth and Environment 42:82-89.

666 Zhou GY, Liu SG, Li ZA, Zhang DQ, Tang XL, Zhou CY, Yan JH, and Mo JM. 2006. Old-growth forests can 667 accumulate carbon in soils. Science 314:1417-1417.

668 Zhou WM, Lewis BJ, Wu SN, Yu DP, Zhou L, Wei YW, and Dai LM. 2014. Biomass carbon storage and its 669 sequestration potential of afforestation under natural forest protection program in China. Chinese Geographical Science 24:406-413. 10.1007/s11769-014-0702-5

671 Zhou YR, Yu ZL, and Zhao SD. 2000. Carbon storage and budget of major Chinese forest types. Chinese Journal of 672 Plant Ecology 24:518-522. 
Figure 1

Location of the study area and sampling plots

Dot points represent the geographical location of 39 sample plots of spruce forest.
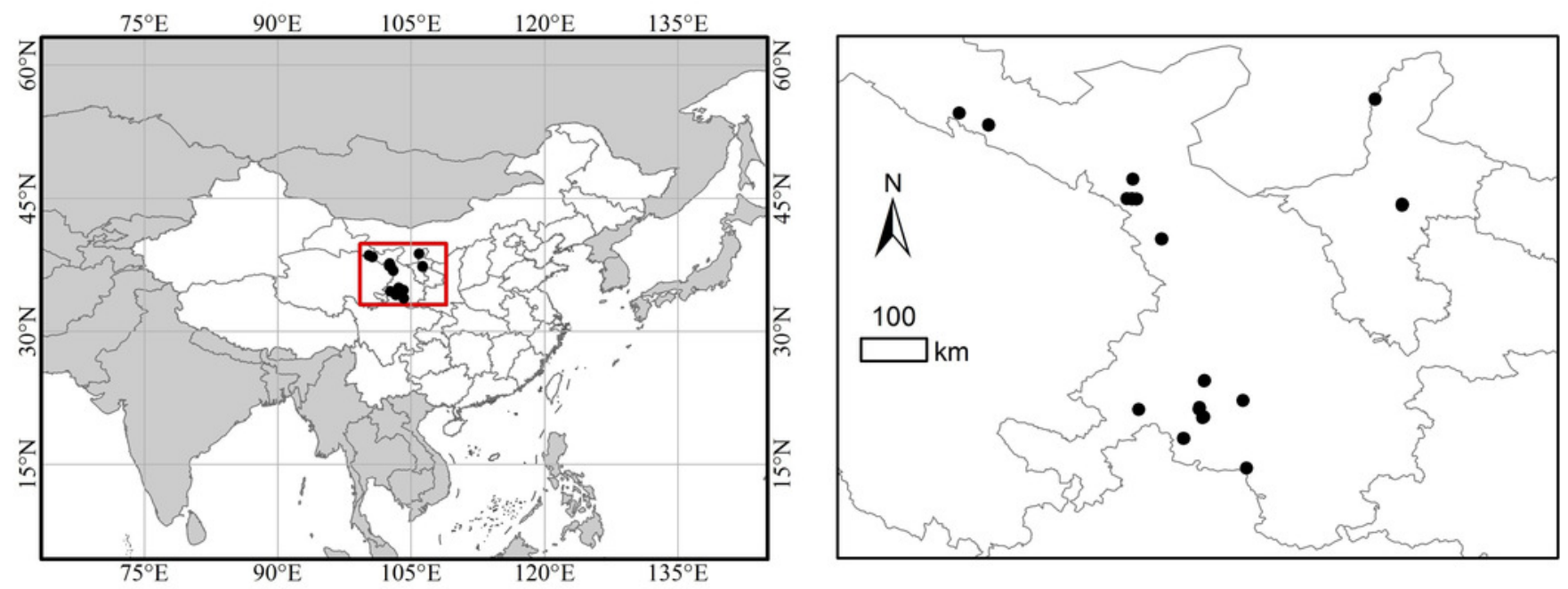


\section{Figure 2 (on next page)}

The relationships between carbon stock in different components and stand age.

a: shrub layer; b: herb layer; c: biomass. 

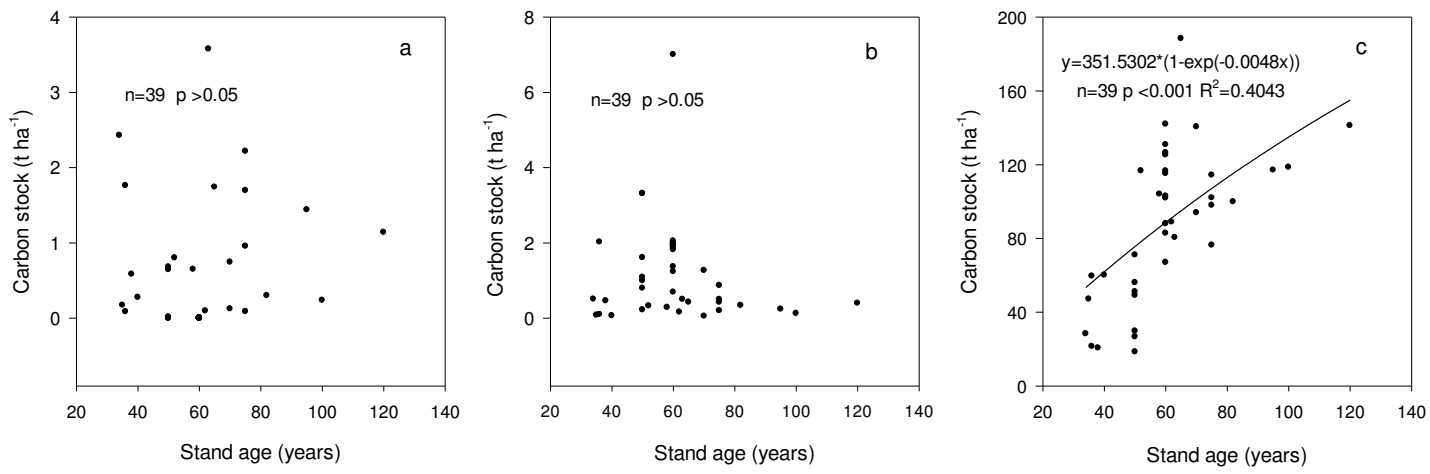


\section{Figure 3 (on next page)}

Biomass carbon sequestration potential (a) and rate (b).

I, II, III and IV indicate the stand age interval: $<40,40-60,60-80$, and $>80$ years while I-II, II-III and III-IV indicate the growth stage of forest during 37-56, 56-70 and 70-104 years, respectively. 

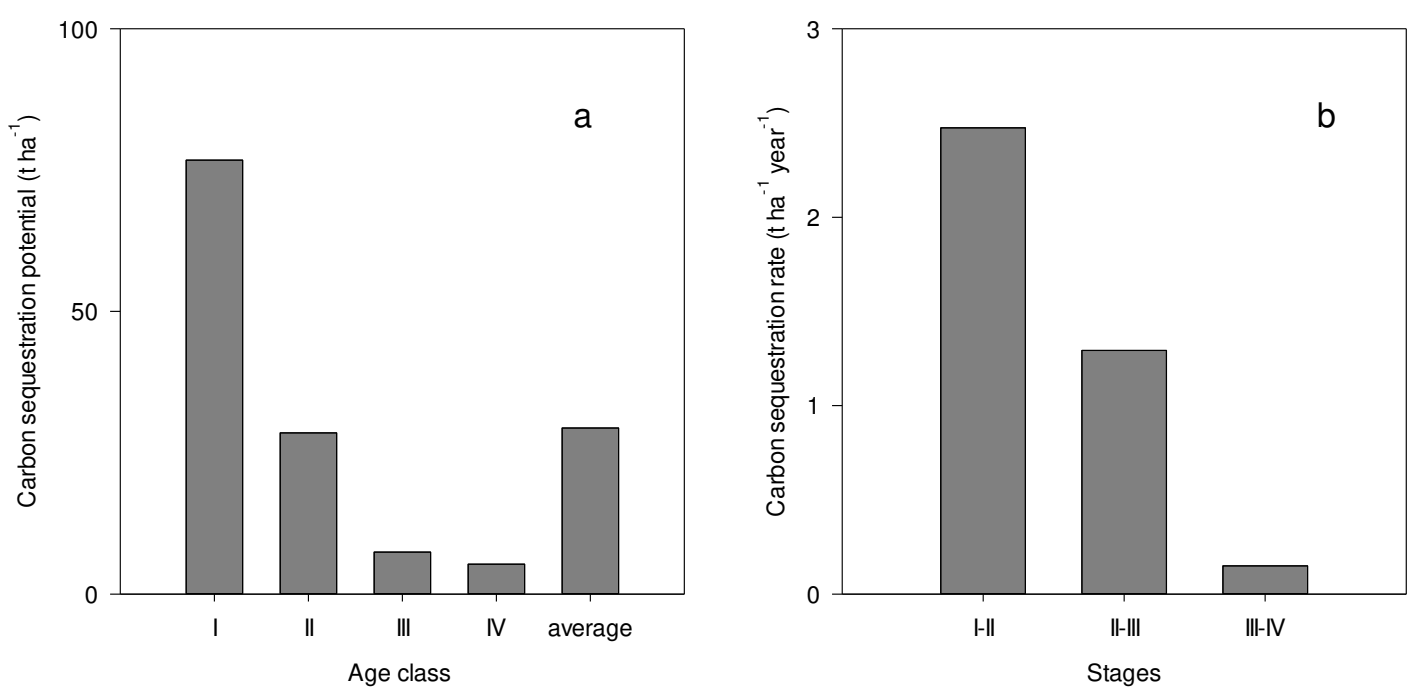


\section{Table 1 (on next page)}

Site characteristics of the natural spruce forests 
1 Table 1. Site characteristics of the natural spruce forests

\begin{tabular}{lcccc}
\hline Stand age classes & I $(<40$ yr $)$ & II $(40-60 \mathrm{yr})$ & III $(60-80 \mathrm{yr})$ & IV $(>80 \mathrm{yr})$ \\
\hline No. of plots & 6 & 20 & 9 & 4 \\
Elevation (m) & $2548 \pm 86$ & $2801 \pm 34$ & $2715 \pm 59$ & $2849 \pm 101$ \\
Density (trees ha-1) & $2877 \pm 305$ & $1682 \pm 165$ & $1591 \pm 344$ & $1637 \pm 148$ \\
Height (m) & $5.2 \pm 0.1$ & $11.0 \pm 0.1$ & $9.3 \pm 0.2$ & $8.8 \pm 0.2$ \\
DBH (cm) & $7.9 \pm 0.1$ & $14.4 \pm 0.2$ & $15.1 \pm 0.4$ & $16.4 \pm 0.5$ \\
Basal area $\left(\mathrm{m}^{2} \mathrm{ha}^{-1}\right)$ & $19.0 \pm 1.7$ & $38.2 \pm 3.5$ & $39.7 \pm 3.9$ & $49.7 \pm 5.1$ \\
\hline
\end{tabular}

2 


\section{Table 2 (on next page)}

Biomass equations of the dominant species and three common companion species

Species No: 1. P. asperata and P. crassifolia 2. Populus davidiana 3. Salix caprea and S. rehderiana 4. Betula utilis. Equations for species No 1 and 4 were obtained from Cheng et al. (2007); and No 2 and 3 were obtained from the protocol edited by Forest Carbon Sequestration Project Office (2014) . 
2 Table 2. Biomass equations of the dominant species and three common companion species

\begin{tabular}{lccccc}
\hline $\begin{array}{l}\text { Species } \\
\text { No. }\end{array}$ & Stem & Branch & Needle & Root & Bark \\
\hline 1 & $\mathrm{e}^{-3.9744}\left(\mathrm{D}^{2} \mathrm{H}\right)^{0.9434}$ & $\mathrm{e}^{-4.6350}\left(\mathrm{D}^{2} \mathrm{H}\right)^{0.9257}$ & $\mathrm{e}^{-5.9391}\left(\mathrm{D}^{2} \mathrm{H}\right)^{0.9753}$ & $\mathrm{e}^{-5.2791}\left(\mathrm{D}^{2} \mathrm{H}\right)^{0.9457}$ & $\mathrm{e}^{-5.5587}\left(\mathrm{D}^{2} \mathrm{H}\right)^{0.8930}$ \\
2 & $0.4944\left(\mathrm{D}^{2} \mathrm{H}\right)^{0.6370}$ & $1.0157\left(\mathrm{D}^{2} \mathrm{H}\right)^{0.4372}$ & $1.3368\left(\mathrm{D}^{2} \mathrm{H}\right)^{0.2537}$ & $0.5060\left(\mathrm{D}^{2} \mathrm{H}\right)^{0.4969}$ & \\
3 & $0.021\left(\mathrm{D}^{2} \mathrm{H}\right)^{0.9642}$ & $0.0011\left(\mathrm{D}^{2} \mathrm{H}\right)^{1.1909}$ & $0.0022\left(\mathrm{D}^{2} \mathrm{H}\right)^{0.8595}$ & $0.053\left(\mathrm{D}^{2} \mathrm{H}\right)^{0.7452}$ & \\
4 & $\mathrm{e}^{-3.8023}\left(\mathrm{D}^{2} \mathrm{H}\right)^{0.9631}$ & $\mathrm{e}^{-5.9070}\left(\mathrm{D}^{2} \mathrm{H}\right)^{1.0903}$ & $\mathrm{e}^{-3.9108}\left(\mathrm{D}^{2} \mathrm{H}\right)^{0.6104}$ & $\mathrm{e}^{-3.2756}\left(\mathrm{D}^{2} \mathrm{H}\right)^{0.7692}$ & \\
\hline
\end{tabular}

3 Species No: 1. P. asperata and P. crassifolia $\quad$ 2. Populus davidiana $\quad$ 3. Salix caprea and S. rehderiana 4.

4 Betula utilis. Equations for species No 1 and 4 were obtained from Cheng et al. (2007); and No 2 and 3 were 5 obtained from the protocol edited by Forest Carbon Sequestration Project Office (2014). 


\section{Table 3 (on next page)}

Distribution pattern and dynamics of carbon stock in tree layer ( $\mathrm{t} \mathrm{ha}^{-1}$ )

For each component, data with different superscript letters are statistically different among different stand age classes. Data are expressed as mean and standard errors. Carbon stock for stem in this study was the sum of stem wood and bark. 
1 Table 3. Distribution pattern and dynamics of carbon stock in tree layer $\left(\mathrm{t} \mathrm{ha}^{-1}\right)$

\begin{tabular}{lcccccccccc}
\hline Tree & \multicolumn{10}{c}{ Stand age classes } \\
component & I & $\%$ & II & $\%$ & III & $\%$ & IV & $\%$ & Average & $\%$ \\
\hline Stem & $14.7 \pm 26^{\mathrm{a}}$ & 52.3 & $42.0 \pm 4.5^{\mathrm{b}}$ & 52.6 & $52.3 \pm 7.8^{\mathrm{b}}$ & 56.5 & $54.3 \pm 3.3^{\mathrm{b}}$ & 57.8 & $41.4 \pm 3.5$ & 54.3 \\
Branch & $4.2 \pm 0.6^{\mathrm{a}}$ & 15.1 & $17.5 \pm 1.9^{\mathrm{b}}$ & 21.8 & $16.6 \pm 3.7^{\mathrm{b}}$ & 18.0 & $15.0 \pm 4.3^{\mathrm{ab}}$ & 16.0 & $15.0 \pm 1.5$ & 19.6 \\
Needle & $4.2 \pm 1.2^{\mathrm{a}}$ & 14.7 & $8.3 \pm 0.9^{\mathrm{b}}$ & 10.4 & $9.9 \pm 1.3^{\mathrm{b}}$ & 10.7 & $9.9 \pm 0.8^{\mathrm{b}}$ & 10.6 & $8.2 \pm 0.6$ & 10.8 \\
Root & $5.0 \pm 1.1^{\mathrm{a}}$ & 17.9 & $12.1 \pm 1.2^{\mathrm{b}}$ & 15.2 & $13.7 \pm 1.8^{\mathrm{b}}$ & 14.8 & $14.7 \pm 0.6^{\mathrm{b}}$ & 15.6 & $11.7 \pm 0.9$ & 15.3 \\
Tree layer & 28.1 & 100 & 79.9 & 100 & 92.4 & 100 & 93.9 & 100 & 76.3 & 100 \\
\hline
\end{tabular}

2 For each component, data with different superscript letters are statistically different among different stand age

3 classes. Data are expressed as mean and standard errors. Carbon stock for stem in this study was the sum of 4 stem wood and bark.

5 


\section{Table 4(on next page)}

Carbon stock in shrubs and herbs (t ha ${ }^{-1}$ ) and the percentage (\%) in different stand age classes

For each component, data with different superscript letters are statistically different among different stand age classes. Data are mean and standard errors. 
1 Table 4. Carbon stock in shrubs and herbs $\left(\mathrm{t} \mathrm{ha}^{-1}\right)$ and the percentage $(\%)$ in different stand 2 age classes

\begin{tabular}{lcccccccccc}
\hline \multirow{2}{*}{ Components } & \multicolumn{1}{c}{ Stand age classes } & & & & \\
& I & $\%$ & II & $\%$ & III & $\%$ & IV & $\%$ & Average & $\%$ \\
\hline Branch & $0.58 \pm 0.31^{\mathrm{a}}$ & 65.91 & $0.07 \pm 0.03^{\mathrm{b}}$ & 50.00 & $0.52 \pm 0.16^{\mathrm{a}}$ & 41.27 & $0.40 \pm 015^{\mathrm{a}}$ & 50.77 & 0.24 & 41.38 \\
Leaf & $0.02 \pm 0.0^{\mathrm{a}}$ & 2.27 & $0.03 \pm 0.02^{\mathrm{a}}$ & 21.43 & $0.07 \pm 0.02^{\mathrm{a}}$ & 5.56 & $0.05 \pm 0.01^{\mathrm{a}}$ & 5.87 & 0.04 & 6.90 \\
Root & $0.28 \pm 0.19^{\mathrm{a}}$ & 31.82 & $0.04 \pm 0.02^{\mathrm{a}}$ & 28.57 & $0.67 \pm 0.24^{\mathrm{a}}$ & 53.17 & $0.34 \pm 0.14^{\mathrm{a}}$ & 43.36 & 0.3 & 51.72 \\
Shrub total & 0.88 & 100 & 0.14 & 100 & 1.26 & 100 & 0.78 & 100 & 0.58 & 100 \\
Aboveground & $0.11 \pm 0.04^{\mathrm{a}}$ & 20.37 & $1.17 \pm 0.25^{\mathrm{b}}$ & 65.00 & $0.16 \pm 0.03^{\mathrm{a}}$ & 32.65 & $0.14 \pm 0.03^{\mathrm{a}}$ & 48.15 & 0.66 & 57.89 \\
Belowground & $0.43 \pm 0.27^{\mathrm{a}}$ & 79.63 & $0.63 \pm 0.11^{\mathrm{a}}$ & 35.00 & $0.33 \pm 0.10^{\mathrm{a}}$ & 67.35 & $0.14 \pm 0.03^{\mathrm{a}}$ & 51.85 & 0.48 & 42.11 \\
Herb total & 0.54 & 100 & 1.80 & 100 & 0.49 & 100 & 0.27 & 100 & 1.14 & 100 \\
\hline
\end{tabular}

3 For each component, data with different superscript letters are statistically different among diferent stand age classes.

4 Data are mean and standard errors. 


\section{Table 5 (on next page)}

Soil organic carbon content at different soil depths with stand age class $\left(\mathrm{g} \mathrm{kg}^{-1}\right)$

Data with different lowercase letters are significantly different among different soil depths within the same age class, while those with different uppercase letters are significantly different among different age classes within the same horizon $(p<0.05)$. Data are mean and standard errors. 
1 Table 5. Soil organic carbon content at different soil depths with stand age class $\left(\mathrm{g} \mathrm{kg}^{-1}\right)$

\begin{tabular}{lccccc}
\hline \multirow{2}{*}{ Soil layer } & \multicolumn{5}{c}{ Stand age class } \\
& I & II & III & IV & Average \\
\hline $0-10 \mathrm{~cm}$ & $91.71 \pm 13.8^{\mathrm{Aa}}$ & $81.74 \pm 5.61^{\mathrm{Aa}}$ & $86.48 \pm 15^{\mathrm{Aa}}$ & $81.25 \pm 14.12^{\mathrm{Aa}}$ & $84.30 \pm 4.99$ \\
$10-20 \mathrm{~cm}$ & $64.8 \pm 14.49^{\mathrm{Aab}}$ & $73.12 \pm 4.8^{\mathrm{Aa}}$ & $63.95 \pm 10.48^{\mathrm{Aab}}$ & $48.61 \pm 3.02^{\mathrm{Ab}}$ & $67.21 \pm 4.13$ \\
$20-30 \mathrm{~cm}$ & $46.75 \pm 12.12^{\mathrm{Abc}}$ & $57.68 \pm 4 \mathrm{Ab}$ & $41.01 \pm 9.27^{\mathrm{Abc}}$ & $31.36 \pm 4.84^{\mathrm{Abc}}$ & $49.45 \pm 3.7$ \\
$30-50 \mathrm{~cm}$ & $31.38 \pm 14.85^{\mathrm{ABbc}}$ & $50.69 \pm 4.73^{\mathrm{Bbc}}$ & $27.93 \pm 6.98^{\mathrm{Ac}}$ & $24.55 \pm 5.18^{\mathrm{Ac}}$ & $39.79 \pm 3.92$ \\
$50-100 \mathrm{~cm}$ & $15.01 \pm 7.12^{\mathrm{Ac}}$ & $41.05 \pm 5.63^{\mathrm{Bc}}$ & $21.17 \pm 5.52^{\mathrm{Ac}}$ & $17.06 \pm 7.67^{\mathrm{Ac}}$ & $30.00 \pm 3.82$
\end{tabular}

2 Data with different lowercase letters are significantly different among different soil depths within the same age class,

3 while those with different uppercase letters are significantly different among different age classes within the same

4 horizon $(p<0.05)$. Data are mean and standard errors.

5 


\section{Table 6(on next page)}

Soil organic carbon stock (t ha ${ }^{-1}$ ) and percentage (\%) indifferent soil layers 
1 Table 6. Soil organic carbon stock $\left(\mathrm{t} \mathrm{ha}^{-1}\right)$ and percentage (\%) in different soil layers

\begin{tabular}{|c|c|c|c|c|c|c|c|c|c|c|}
\hline \multirow{2}{*}{$\begin{array}{l}\text { Soil depth } \\
\text { (cm) }\end{array}$} & \multicolumn{10}{|c|}{ Stand age classes } \\
\hline & I & $\%$ & II & $\%$ & III & $\%$ & IV & $\%$ & Average & $\%$ \\
\hline $0-10$ & $70.4 \pm 9.0^{\mathrm{a}}$ & 23.1 & $48.1 \pm 4.7^{\mathrm{a}}$ & 11.5 & $46.7 \pm 3.8^{\mathrm{a}}$ & 15.4 & $67.4 \pm 20.6^{\mathrm{a}}$ & 26.5 & $53.2 \pm 3.7$ & 14.9 \\
\hline $10-20$ & $52.7 \pm 7.39^{\mathrm{a}}$ & 17.2 & $50.1 \pm 5.4^{\mathrm{a}}$ & 11.9 & $47.9 \pm 4.1^{\mathrm{a}}$ & 15.8 & $39.8 \pm 5.3^{\mathrm{a}}$ & 15.7 & $48.9 \pm 3.1$ & 13.6 \\
\hline $20-30$ & $43.2 \pm 7.8^{\mathrm{a}}$ & 14.1 & $44.1 \pm 3.4^{\mathrm{a}}$ & 10.5 & $33.4 \pm 6.6^{\mathrm{a}}$ & 11.0 & $30.9 \pm 2.4^{\mathrm{a}}$ & 12.2 & $40.1 \pm 2.7$ & 11.2 \\
\hline $30-50$ & $58.9 \pm 26.4^{\mathrm{a}}$ & 19.2 & $85.6 \pm 8.8^{\mathrm{a}}$ & 20.4 & $55.8 \pm 14.3^{\mathrm{a}}$ & 18.3 & $52.2 \pm 10.3^{\mathrm{a}}$ & 20.5 & $71.2 \pm 7.1$ & 19.8 \\
\hline $50-100$ & $80.9 \pm 38.0^{\mathrm{a}}$ & 26.4 & $192.1 \pm 24.2^{\mathrm{b}}$ & 45.7 & $120.3 \pm 31.9^{\mathrm{ab}}$ & 39.5 & $64.0 \pm 41^{\mathrm{a}}$ & 25.1 & $145.3 \pm 17.6$ & 40.5 \\
\hline $0-100$ & 306.1 & 100 & 420.0 & 100 & 304.1 & 100 & 254.2 & 100 & 358.7 & 100 \\
\hline
\end{tabular}


Table 7 (on next page)

Carbon stock of each layer $\left(\mathrm{t} \mathrm{ha}^{-1}\right)$ in the ecosystem for different age classes 
1 Table 7. Carbon stock of each layer $\left(\mathrm{t} \mathrm{ha}^{-1}\right)$ in the ecosystem for different age classes

\begin{tabular}{|c|c|c|c|c|c|c|c|c|c|c|}
\hline \multirow{2}{*}{$\begin{array}{l}\text { Ecosystem } \\
\text { component }\end{array}$} & \multicolumn{10}{|c|}{ Stand age classes } \\
\hline & I & $\%$ & II & $\%$ & III & $\%$ & IV & $\%$ & Average & $\%$ \\
\hline Tree & $28.1 \pm 5.2^{\mathrm{a}}$ & 8.1 & $79.9 \pm 8.4^{b}$ & 15.7 & $92.4 \pm 14.2^{\mathrm{b}}$ & 22.3 & $93.9 \pm 8.8^{b}$ & 25.2 & $76.3 \pm 6.4$ & 17 \\
\hline Shrub & $0.9 \pm 0.4^{\mathrm{a}}$ & 0.3 & $0.14 \pm 0.1^{\mathrm{a}}$ & 0 & $1.3 \pm 0.4^{\mathrm{a}}$ & 0.3 & $0.8 \pm 0.3^{\mathrm{a}}$ & 0.2 & $0.58 \pm 0.2$ & 0.1 \\
\hline Herb & $0.5 \pm 0.3^{\mathrm{a}}$ & 0.2 & $1.8 \pm 0.3^{\mathrm{b}}$ & 0.4 & $0.5 \pm 0.1^{\mathrm{ac}}$ & 0.1 & $0.3 \pm 0.1^{\mathrm{ac}}$ & 0.1 & $1.1 \pm 0.2$ & 0.3 \\
\hline Fine root & $3.8 \pm 0.9^{\mathrm{a}}$ & 1.1 & $5.5 \pm 0.7^{\mathrm{a}}$ & 1.1 & $4.1 \pm 2.7^{\mathrm{a}}$ & 1.0 & $3.9 \pm 0.9^{\mathrm{a}}$ & 1.0 & $4.4 \pm 0.4$ & 1.0 \\
\hline Deadwood & $0.6 \pm 0.3^{\mathrm{a}}$ & 0.2 & $1.3 \pm 0.7^{\mathrm{ab}}$ & 0.3 & $4.6 \pm 0.9^{b c}$ & 1.1 & $8.7 \pm 1.5^{\mathrm{c}}$ & 2.3 & $3.7 \pm 1.1$ & 0.8 \\
\hline Litter & $5.6 \pm 1.9^{a b}$ & 1.6 & $1.5 \pm 0.2^{\mathrm{b}}$ & 0.3 & $7.3 \pm 3.2^{\mathrm{a}}$ & 1.8 & $11.7 \pm 7.0^{\mathrm{a}}$ & 3.1 & $4.5 \pm 1.1$ & 1.0 \\
\hline Biomass total & $39.5 \pm 7.5 \mathrm{a}$ & 11.4 & $90.2 \pm 8.5^{\mathrm{b}}$ & 17.7 & $\begin{array}{c}110.2 \pm 11.8 \\
\mathrm{~b}\end{array}$ & 26.6 & $119.1 \pm 8.5^{\mathrm{b}}$ & 31.9 & $90.7 \pm 6.5$ & 20.2 \\
\hline Soil & $306.1 \pm 81.1^{\mathrm{a}}$ & 88.6 & $420.0 \pm 31.0^{\mathrm{a}}$ & 82.3 & $304.1 \pm 54.7^{\mathrm{a}}$ & 73.4 & $254.2 \pm 42.4^{\mathrm{a}}$ & 68.1 & $358.7 \pm 25.5$ & 79.8 \\
\hline Ecosystem & $345.6 \pm 74.8^{\mathrm{a}}$ & 100 & $510.1 \pm 34.2^{\mathrm{a}}$ & 100 & $414.2 \pm 52.6^{\mathrm{a}}$ & 100 & $373.3 \pm 45.9^{\mathrm{a}}$ & 100 & $449.4 \pm 26.0$ & 100 \\
\hline
\end{tabular}

2 